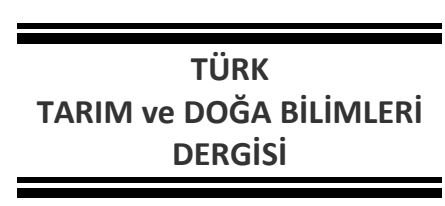

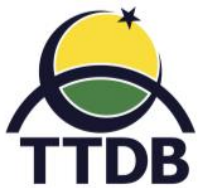

www.dergipark.gov.tr/turkjans

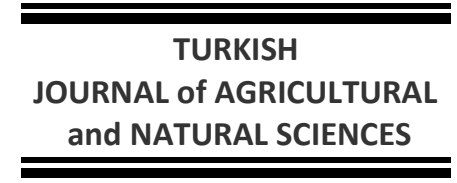

Research Article

\title{
Investigating Combination and Individual Impact of Phosphorus and Humic Acid on Yield of Wheat and Some Soil Properties
}

\author{
Aftab JAMAL ${ }^{1 *}$, Iqrar HUSSAIN ${ }^{1}$, Muhammad Sarirullah SARIR ${ }^{1}$, Muhammad SHARIF ${ }^{1}$, Muhammad FAWAD ${ }^{2}$ \\ ${ }^{1}$ Department of Soil and Environmental Sciences, the University of Agriculture Peshawar, Pakistan. \\ ${ }^{2}$ Department of Weed Science, the University of Agriculture Peshawar, Pakistan. \\ *Corresponding author: aftabses98@gmail.com
}

\begin{abstract}
Received: 02.06.2018
Revised in Received: 09.08.2018

Accepted: 31.08 .2018

\section{Abstract}

In order to evaluate the effect of different levels of Phosphorous (P) alone and in combination with Humic acid (HA) on the yield and $P$ accumulation by wheat(TriticumaestivumL, CV Fakhr-e-Sarhad)., a field experiment was carried out at agriculture research station of Swabi, Pakistan during 2016-2017. A total of eight treatments replicated four times were arranged in Randomized Complete Block Design (RCBD) in the field. Two levels of $\mathrm{HA}$ including control ( $\mathrm{HO}$ : control and $\left.\mathrm{H1}: 500 \mathrm{~g} \mathrm{ha}^{-1}\right)$ and four levels of $\mathrm{P}\left(\mathrm{P}_{2} \mathrm{O}_{5}\right)$ including control as Single Super Phosphate (SSP) (P0: control, P1: $60 \mathrm{~kg} \mathrm{ha}^{-1}, \mathrm{P} 2: 90 \mathrm{~kg} \mathrm{ha}^{-1}$, and P3: $150 \mathrm{~kg} \mathrm{ha}^{-1}$ ) were utilized. ; Size of each plot was kept to $5 \times 4 \mathrm{~m}$. Addition of different levels of SSP alone and in combination with HA significantly $(\mathrm{P}<0.05)$ improved straw, grain and total wheat yield over control. HA in combination with 60 and $90 \mathrm{~kg} \mathrm{P}_{2} \mathrm{O}_{5} \mathrm{ha}^{-1}$ improved the grain yield by 22.4 and $6.5 \%$ respectively as compared to the same amount of fertilizer applied alone. Total yield (Dry mass + Grains) of $20877 \mathrm{~kg} \mathrm{ha}^{-1}$ was produced by the treatment P2H1 $\left(90 \mathrm{~kg} \mathrm{P}_{2} \mathrm{O}_{5} \mathrm{ha}^{-1}+500 \mathrm{~g} \mathrm{ha}^{-1} \mathrm{HA}\right)$ followed by the treatment $\mathrm{P} 2 \mathrm{H0}$, which were 78.69 and $75.03 \%$ increases over the control. Significantly highest 1000 - grain weight of $47.8 \mathrm{~g}$ was recorded in the treatment $\mathrm{P} 2 \mathrm{H} 1$ while all other treatments showed non-significant increase in 1000- grain weight. Unlike soil pH values, improvement in the Soil Organic Matter content (SOM) was observed with the application of both HA and chemical fertilizers either applied alone or in combination. SSP applied either alone or in combination with HA increased significantly $(P<0.05)$ the post-harvest soil $P$ concentration as well as $P$ accumulation by wheat plants over control. Results suggest that application $90 \mathrm{~kg} \mathrm{P}_{2} \mathrm{O}_{5} \mathrm{ha}^{-1}$ reinforced with $\mathrm{HA}(\mathrm{P} 2 \mathrm{H} 1)$ may be considered as an optimum dosage for achieving optimum yield of wheat crop.
\end{abstract}

Key words: Humic acid, phosphorous, wheat, soil.

\section{Introduction}

Wheat (TriticumaestivumL.), belongs to family Poaceae and known as king of cereals. It is cultivated on a vast area about 8.1 million ha of Pakistan and used as a staple meal, contributes $83 \%$ of total cereal intake and used as a cheap nutritional diet provides $50 \%$ of the total calories and $60 \%$ of proteins consumed by total population of Pakistan. Although Pakistan is the $10^{\text {th }}$ largest wheat producing country, produced an average yield of $2384 \mathrm{~kg} \mathrm{ha}^{-1}$ of wheat yet its production is far below than its actual production potential of $6450 \mathrm{~kg} \mathrm{ha}^{-1}$, creates an enormous scope for increased output (MINFA, 2011).

Humic acid is a multifarious molecule of polymeric organic acid of aromatic structure replaced by carboxyl, phenolic, hydroxyl and alkyl groups associated together through ether linkage (Sutton and Sposito, 2005) and accumulates in environment as a result of decomposition of organic matter (Stott and Martin, 1990) and might be useful for crop growth by its chelating property and buffering $\mathrm{pH}(J u l i e$ and Bugbee, 2006). It is considered as one of the active constituents of organic fertilizers used as a cheap fertilizer to improve crop growth, yield, soil organic matter content as well as physical condition of the soil ( $\mathrm{Li}$ et al., 2017; Karakurt et al., 2009).

Significance of HA in crop production have been consistently reported and it might be utalized as fertilizer in agriculture, in turn improve crop growth, nutrients uptake as well as soil 
moisture (Sharif et al., 2002; Cheryl et al., 2001). In alkaline calcareous soil the availability of nutrients is often low due to adsorption property and HA is used to convert these unavailable forms into chelating complex due to the existence of functional groups and increased nutrients uptake by crops (Chen et al., 2004) or by the presence of auxin or auxin-like compounds (Aguirre et al., 2009). HA has the ability of supplying $N$ and $P$ to the plants as it is the primary constituent of organic Carbon, Nitrogen and Phosphorous (Khattak and Muhammad, 2008,; Sharif et al., 2002). Published literature revealed that coapplication of HA with either single nutrient or mixed with NPK fertilizers significantly increased the yield of crops (Selimet al., 2009). Ezzatet al., 2009 recorded $33 \%$ increase in potato yield with K-humate application at $30 \mathrm{Mg} \mathrm{ha}{ }^{-1}$. Similarly in salt affected soil $2 \mathrm{~kg}$ ha $^{-1}$ humic substances along with $\mathrm{Cu}$ and $\mathrm{Zn}$ improved wheat production(Manzooret al., 2014).

On the other hand Phosphorus $(P)$ is one of the essential macro nutrients needed by plants on regular basis and its significant role has long been recognized by several researchers (Ahmad et al., 2013; Naseer and Muhammad, 2014). Calcareous nature and high soil $\mathrm{pH}$ of Pakistani soil reduce the $P$ availability due to sorption and fixation; $P$ fixation can be decreased by interacting with humic substances and ultimately increased the $P$ uptake of crop (Quan-Xian et al., 2008). Phosphorous fertilizer use efficiency by HA have also been reportedby (Delgado et al., 2002).

Keeping in mind the importance of Humic acid (HA) and Phosphorous (P), the present research aimed to study the impact of $\mathrm{HA}$ alone or in combination with $\mathrm{P}$ on wheat crop yield.

\section{Material and Methods Site characteristics}

Experiment was conducted at Agricultural Research Station Swabi located at $34^{\circ} 7^{\prime} 48^{\prime \prime} \mathrm{N}$ and $72^{\circ} 28^{\prime} 11^{\prime \prime} E$ of Khyber PakhtunKhwa, Pakistan, with average rain fall of $300 \mathrm{~mm}$, during 2016-17.

\section{Experimental design and treatments}

Experiment was arranged in Randomized Complete Block Design (RCBD).There were total eight treatments, two levels of humic acid including control ( $\mathrm{HO}$ : control and $\mathrm{H1}$ : $500 \mathrm{~g} \mathrm{ha}^{-1}$ ) and four levels of $\mathrm{P}$ as Single Super Phosphate (SSP) including control (PO: control, P1: $60 \mathrm{~kg} \mathrm{ha}^{-1}$, P2: $90 \mathrm{~kg} \mathrm{ha}^{-1}$, and P3: $150 \mathrm{~kg} \mathrm{ha}^{-1}$ ) replicated four times, which made a total of 32 plots, each of $5 \times 4$ $\mathrm{m}$ size. The row to row distance of wheat plants was $25 \mathrm{~cm}$. Following treatments combination was utilized during the study.

$\begin{array}{ll}\text { Treatment 1 } & \mathrm{POHO} \\ \text { Treatment 2 } & \mathrm{POH} 1 \\ \text { Treatment 3 } & \mathrm{P} 1 \mathrm{HO} \\ \text { Treatment 4 } & \mathrm{P} 1 \mathrm{H} 1 \\ \text { Treatment 5 } & \mathrm{P} 2 \mathrm{H} 0 \\ \text { Treatment 6 } & \mathrm{P} 2 \mathrm{H} 1 \\ \text { Treatment 7 } & \mathrm{P} 3 \mathrm{H} 0 \\ \text { Treatment 8 } & \mathrm{P} 3 \mathrm{H} 1\end{array}$

\section{Soil characteristics}

Analysis of composite soil sample collected at $0-20 \mathrm{~cm}$ depth before the experiment revealed that the soil was silty clay loam in texture, alkaline in reaction, calcareous in nature low in organic matter (OM) content (Table 1). The soil was also found poor in available phosphorous (P).

Table 1. Some soil physico-chemical properties (0$20 \mathrm{~cm}$ depth).

\begin{tabular}{lc}
\hline Property & Value \\
\hline Clay (\%) & 24 \\
Silt (\%) & 46.8 \\
Sand (\%) & 27 \\
Textural class & Silty Clay Loam (SCL) \\
pH (1:5; Soil:Water) & 8.6 \\
Organic matter (\%) & 0.69 \\
Lime (CaCO $)(\%)$ & 16.8 \\
AB-DTPA P ( mg kg-1) & 5.72 \\
AB-DTPA K (mg kg-1) & 150 \\
\hline
\end{tabular}

${ }^{*}$ AB-DTPA = Ammonium Bicarbonate Di-ethylene TriaminePenta Acetic Acid.

\section{Post-harvest soil and plant analysis}

Three central rows were harvested from each treatment plot at maturity stage and the yield parameters, grain yield, Total yield, Straw yield, and 1000-garin weight were recorded.

Data on the grain yield was recorded after threshing the bundles of wheat plants from each treatment and then converted into $\mathrm{kg} \mathrm{ha}^{-1}$ .Thousand grain weight was recorded by counting 1000 grains selected randomly from each treatment and then weighed by electronic balance. Total yield and straw yield were recorded in each treatment after adequate dying and then converted into $\mathrm{kg} \mathrm{ha}^{-1}$. Soil samples collected from each treatment after crop harvest were analyzed for $\mathrm{pH}$ (Richards, 1954), Soil organic matter content (Nelson and Sommers, 1982), Phosphorous and Potassium (Soltanpour 1985). Plant samples selected from each treatment plot were analyzed for plant $P$ and plant accumulations by wheat plants (Walsh and Beaton, 1973). Phosphorous Use Efficiency (PUE) is the percent 
recovery of the applied nutrient in the harvested portion of the crop and PUE were calculated as;

PUE=Pf-Pc /Px100

$\mathrm{Pf}$ and $\mathrm{Pc}$ are total Phosphorous uptake from fertilized and check (control) plots respectively and $\mathrm{P}$ is applied in $\mathrm{kg} \mathrm{ha}^{-1}$ (Latifet al., 2003).

\section{Statistical analysis}

Statistical Analysis of the collected data were done by following the procedures given by Steel and Torrie (1980) using M Stat C package and least significant difference (LSD) test was used for any significant difference among the treatments.

\section{Results and Discussion}

\section{Post-harvest soil $\mathrm{pH}$ and organic matter}

The analysis of data on soil $\mathrm{pH}$ revealed that lowest soil $\mathrm{pH}$ (8.12) was recorded in the treatment $\mathrm{P} 3 \mathrm{H} 1$ followed by $\mathrm{P} 2 \mathrm{H} 1$ (Table 2). The decrease in soil $\mathrm{pH}$ with $\mathrm{HA}$ application was also reported by Mahmoud and Hafez, (2010) stated that during mineralization process of organic and inorganic fertilizers the $\mathrm{H}^{+}$ions released resulted decrease in soil $\mathrm{pH}$, while in another study Ali and Mindari (2016) recorded lower soil pH with addition of $400 \mathrm{ml} \mathrm{HA}$ to $5 \mathrm{~kg}$ soil. Soil organic matter (SOM) content significantly increased over control $(P<0.05)$ with the addition of $P$ alone as well as in combination with HA (Table 2). Maximum SOM content of $1.3 \%$ was recorded in the treatment $\mathrm{P} 3 \mathrm{H} 1$ followed by $1.23 \%$ at treatment $\mathrm{P} 2 \mathrm{H} 1$, however non-significant differences were observed between treatments $\mathrm{POH} 1$ and $\mathrm{P} 1 \mathrm{H} 1$ (Table 2).

In the present study SOM content was improved by $21-45 \%$ with the addition of $\mathrm{HA}$ alone and in combination with $\mathrm{P}$ fertilizer as compared with control (Fig 1). Increases of 11 and $13 \%$ were recorded in SOM, when 60 and $90 \mathrm{~kg} \mathrm{ha}^{-1} \mathrm{P}$ was applied along with $\mathrm{HA}$ as compared to the same rate of $P$ fertilizer applied alone. The increase in SOM content with addition of organic fertilizers was also reported by Khaled and Fawy (2011) concluded that HA increased the organic matter content of the soil and promote the chelation of many elements and increased the chances of availability to plants. Organic materials increased the O.M content of soil up to $1.17-2.85 \mathrm{~kg} \mathrm{ha}^{-1}$ and reduced the oxidation stability of SOM (Wang et al., 2015 and Li et al., 2017).

Table 2. Effect of different levels of Phosphorous alone as well as in combination with humic acid on postharvest soil $\mathrm{pH}$ and $\mathrm{OM}$.

\begin{tabular}{ccc}
\hline Treatments & pH (1:5; Soil: Water) & Organic Matter (\%) \\
\hline${ }^{*} \mathrm{P}_{0} \mathrm{H}_{0}$ & 8.4 & $0.86 \mathrm{~d}^{* *}$ \\
$\mathrm{P}_{0} \mathrm{H}_{1}$ & 8.24 & $1.04 \mathrm{c}$ \\
$\mathrm{P}_{1} \mathrm{H}_{0}$ & 8.21 & $1.03 \mathrm{c}$ \\
$\mathrm{P}_{1} \mathrm{H}_{1}$ & 8.24 & $1.13 \mathrm{bc}$ \\
$\mathrm{P}_{2} \mathrm{H}_{0}$ & 8.20 & $1.12 \mathrm{bc}$ \\
$\mathrm{P}_{2} \mathrm{H}_{1}$ & 8.15 & $1.23 \mathrm{ab}$ \\
$\mathrm{P}_{3} \mathrm{H}_{0}$ & 8.20 & $1.18 \mathrm{ab}$ \\
$\mathrm{P}_{3} \mathrm{H}_{1}$ & 8.12 & $1.30 \mathrm{a}$ \\
\hline
\end{tabular}

*P (P0, P1, P2 and P3): P2O5 levels (control, 60, 90 and $150 \mathrm{~kg} \mathrm{ha}^{-1}$ ) and HA (HO and H1): Humic acid levels (control and $500 \mathrm{~g} \mathrm{ha}^{-1}$ ).

**Means with different letter (s) in columns are significantly different at $p<0.05$.

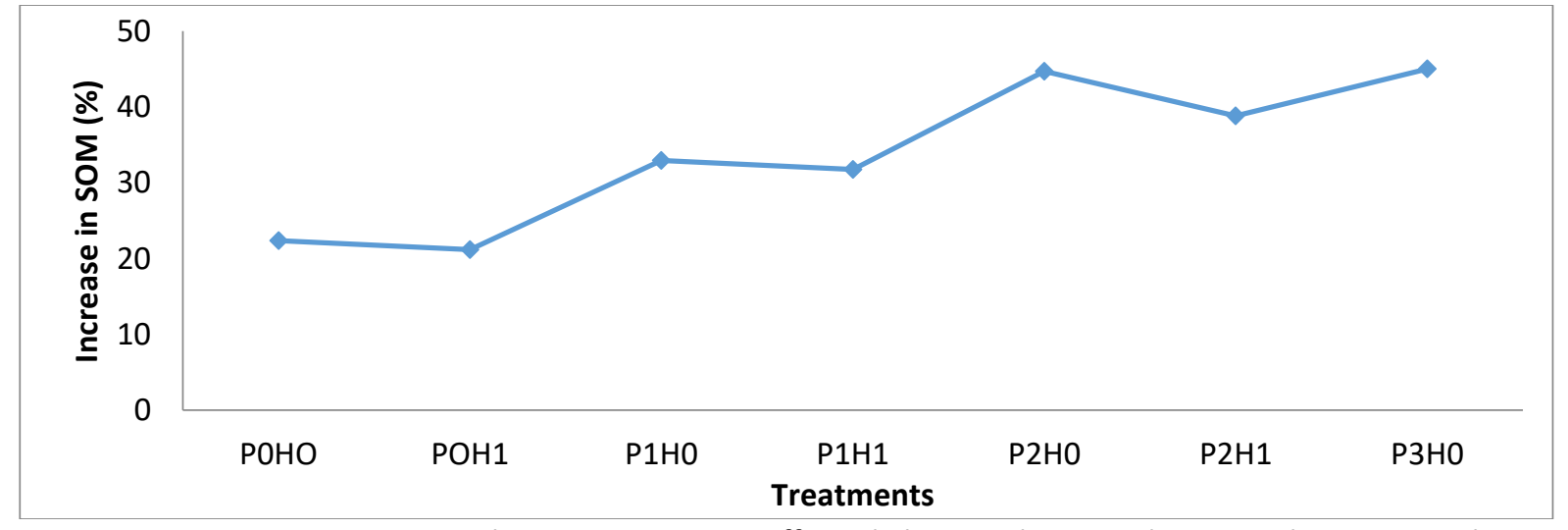

Figure 1. $\%$ increase in post-harvest SOM as effected by $P$ alone and in combination with $H A$. 


\section{Grain yield}

Wheat grain yield significantly increased $(P<0.05)$ over control with addition of $P$ and $H A$. The maximum grain yield of $5112 \mathrm{~kg} \mathrm{ha}^{-1}$ was recorded in the treatment $\mathrm{P} 2 \mathrm{H} 1$. Further increase beyond this level has no effect on yield (Table 3 ). However non-significant differences were found among treatments $\mathrm{P} 2 \mathrm{HO}, \mathrm{P} 2 \mathrm{H} 1, \quad \mathrm{P} 3 \mathrm{HO}$ and $\mathrm{P} 3 \mathrm{H} 1$. Percent increases over control were in the order $\mathrm{P} 2 \mathrm{H} 1>\mathrm{P} 3 \mathrm{H} 1>\mathrm{P} 3 \mathrm{H} 0>\mathrm{P} 2 \mathrm{H} 0>\mathrm{P} 1 \mathrm{H} 1>\mathrm{P} 1 \mathrm{H} 0>\mathrm{POH} 1$

$(74.13,67.41,65.43,63.49,60.00,30.75$, and 27.11 $\%)$, respectively.

Results revealed that HA applied alone $\left(500 \mathrm{~g} \mathrm{ha}^{-1}\right)$ significantly increased the yield from
$2936 \mathrm{~kg} \mathrm{ha}^{-1}$ to $3732 \mathrm{~kg} \mathrm{ha}^{-1}$ which was $27 \%$ as compared with control (Fig.2). 60 and $90 \mathrm{~kg} \mathrm{P}_{2} \mathrm{O}_{5}$ $\mathrm{ha}^{-1}$ along with $500 \mathrm{~g} \mathrm{ha}^{-1} \mathrm{HA}$ increased the grain yield up to $22.4 \%$ and $6.5 \%$ respectively as compared with the same amount of $P$ applied alone. Our results were in lined with Sharif et al., (2002) who studied $25-69 \%$ increases in grain yield over control with HA application. Increased in the grain yield and straw yield of wheat by $26 \%$ and $23.8 \%$ with HA application was also reported (Brunettiet al., 2007). The highest yield $1314 \mathrm{~kg}$ ha1 of rain fed wheat was achieved with the application of HA and inorganic fertilizers (Khan et al.,

2010).

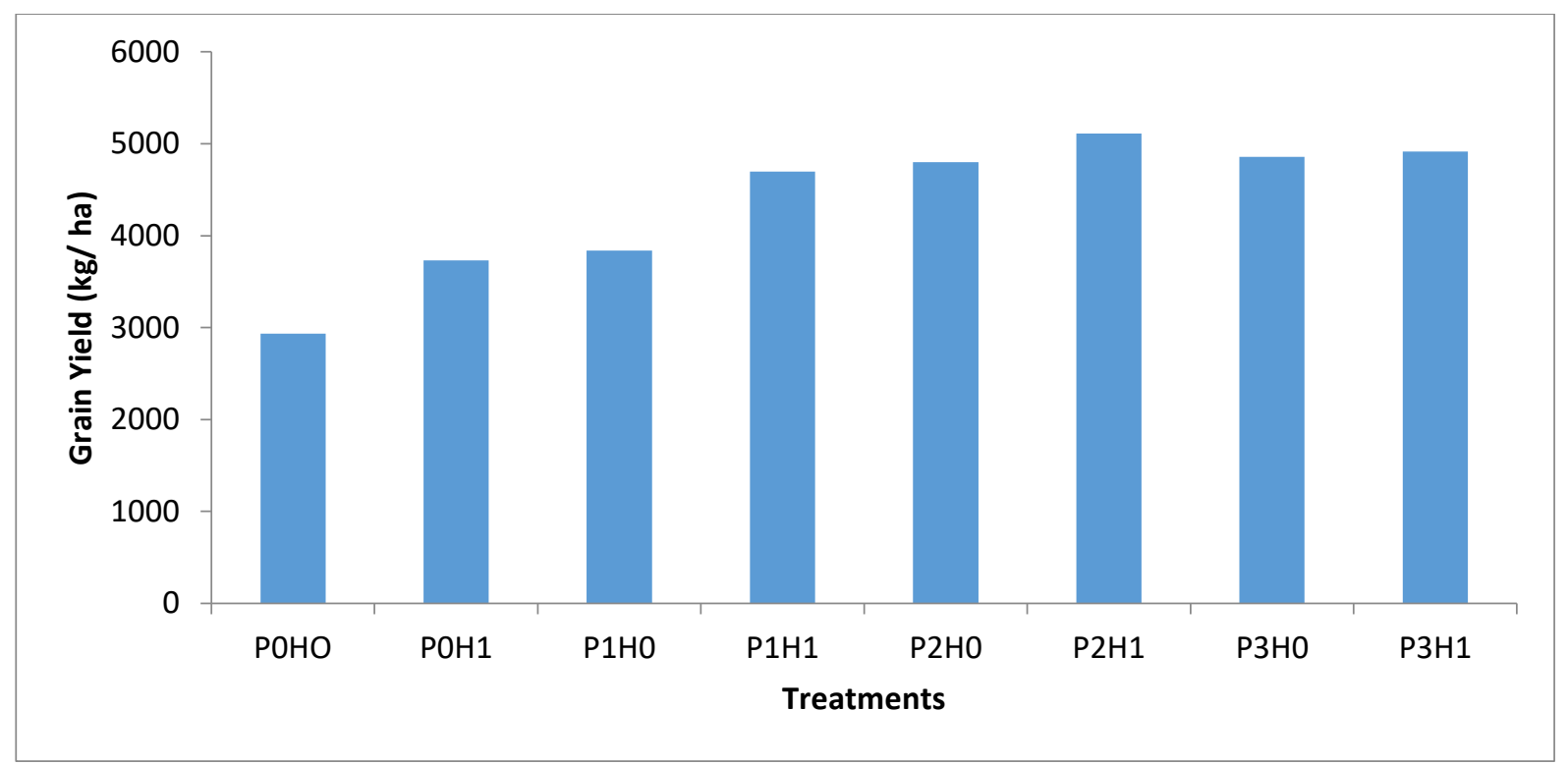

Figure 2. Effect of different treatments on the grain yield of wheat.

\section{Total yield (Dry mass + Grains)}

The increasing trend of total yield with $\mathrm{P}$ and HA was almost similar to that of grain yield (Table 3). All the treatments in different combinations increased the total yield of wheat significantly $(P<0.05)$ over control. Maximum total yield of $20877 \mathrm{~kg} \mathrm{ha}^{-1}$ was obtained from the treatment $\mathrm{P} 2 \mathrm{H} 1$ followed by $20449 \mathrm{~kg} \mathrm{ha}^{-1}$ by treatment $\mathrm{P} 2 \mathrm{HO}$ which were 78.69 and $75.03 \%$ increases over control (Figure 3.). Publish literature reveled $\mathrm{HA}$ alone produced significantly $(P<0.05)$ maximum grain yield of wheat $(2999.9 \mathrm{~kg}$ $\mathrm{ha}^{-1}$ ) and increased the yield by $24 \%$ over the control(Khan et al., 2010), while Delgado et al., (2002) reported that foliar applied humic acid along with split soil $\mathrm{N}$ significantly improved the grain yield as well as grain protein.

\section{Straw yield}

Wheat straw yield significantly increased over control with application of both $\mathrm{P}$ and $\mathrm{HA}$ either alone or in combination. However no significant difference was observed between $P$ fertilizers applied alone or in combinations with $H A$. The significantly maximum straw yield of $15906 \mathrm{~kg} \mathrm{ha}^{-1}$ was obtained from the treatment P2H1 (Table 3 and Figure. 4). However no significant difference was found between treatments $\mathrm{P} 2 \mathrm{HO}$ and $\mathrm{P} 2 \mathrm{H} 1$. Our results were in lined with the findings of (Anwar and Yousaf, 2000) found that wheat under rainfed condition could be increased significantly by the application of both organic and inorganic fertilizers. While in another study it was revealed that effects of $\mathrm{HA}$ and $\mathrm{P}$ application was more effective on growth and growth parameter than each separate effect, the highest total dry matter of peeper plant $(69 \mathrm{mg} \mathrm{kg}$ $\left.{ }^{1}\right)$ was obtained with P application and $1500 \mathrm{mg} \mathrm{HA}$ $\mathrm{kg}^{-1}$ application (Çimrinet al. 2010). 


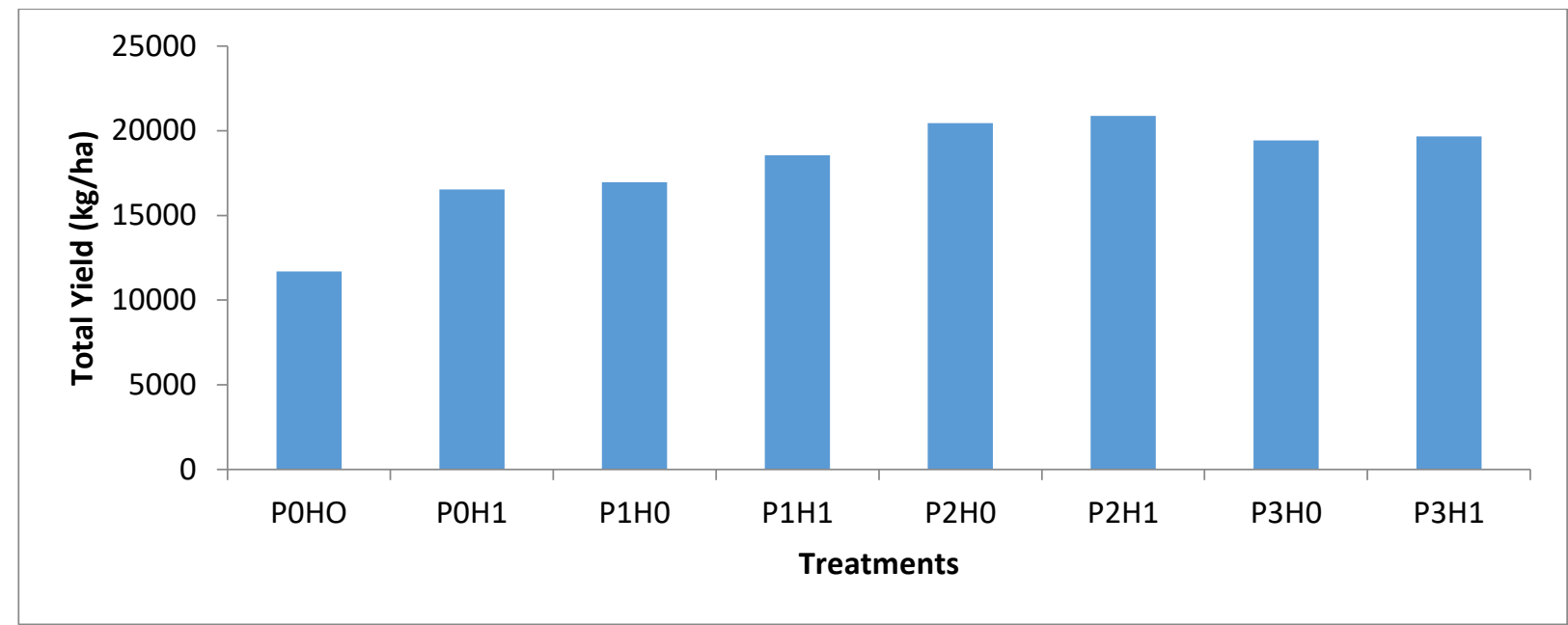

Figure 3. Effect of different treatments on total yield (Dry Mass +Grain) of wheat.

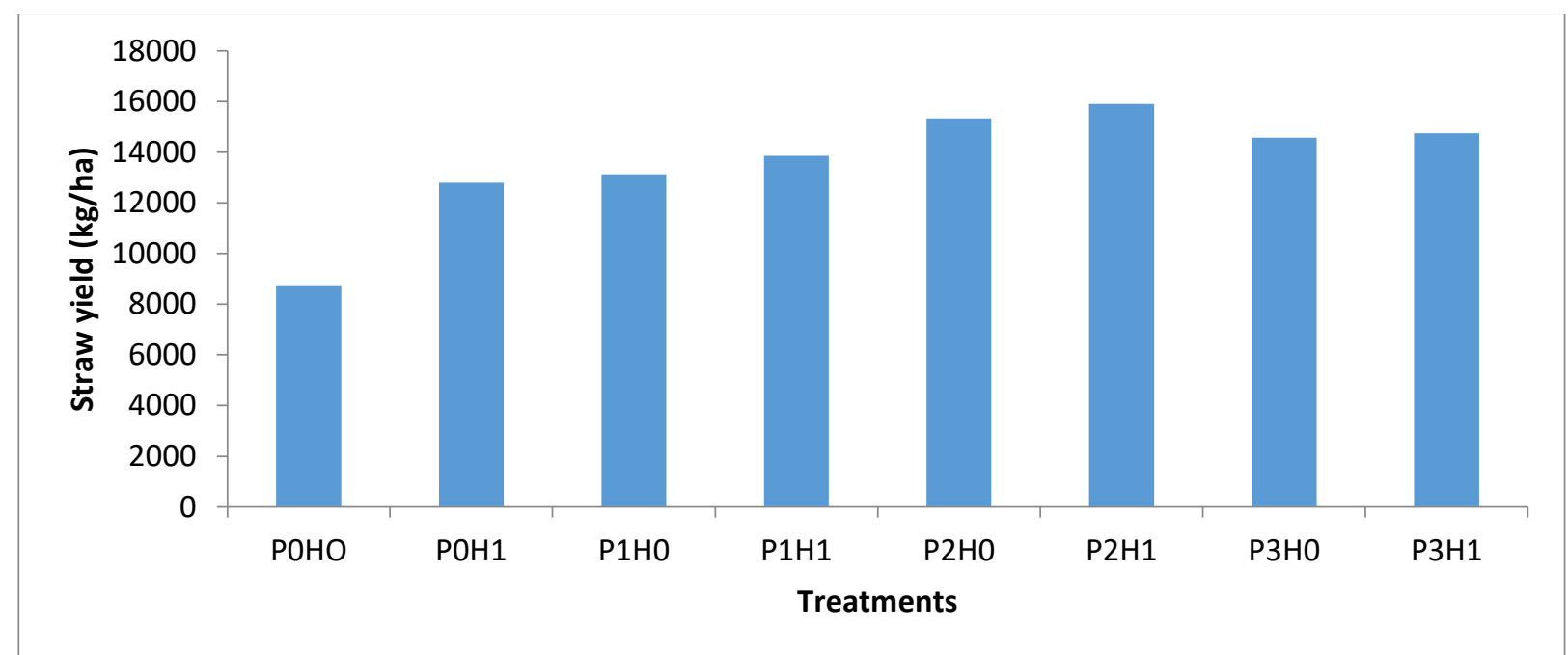

Figure 4. Effect of different treatments on Straw yield of wheat.

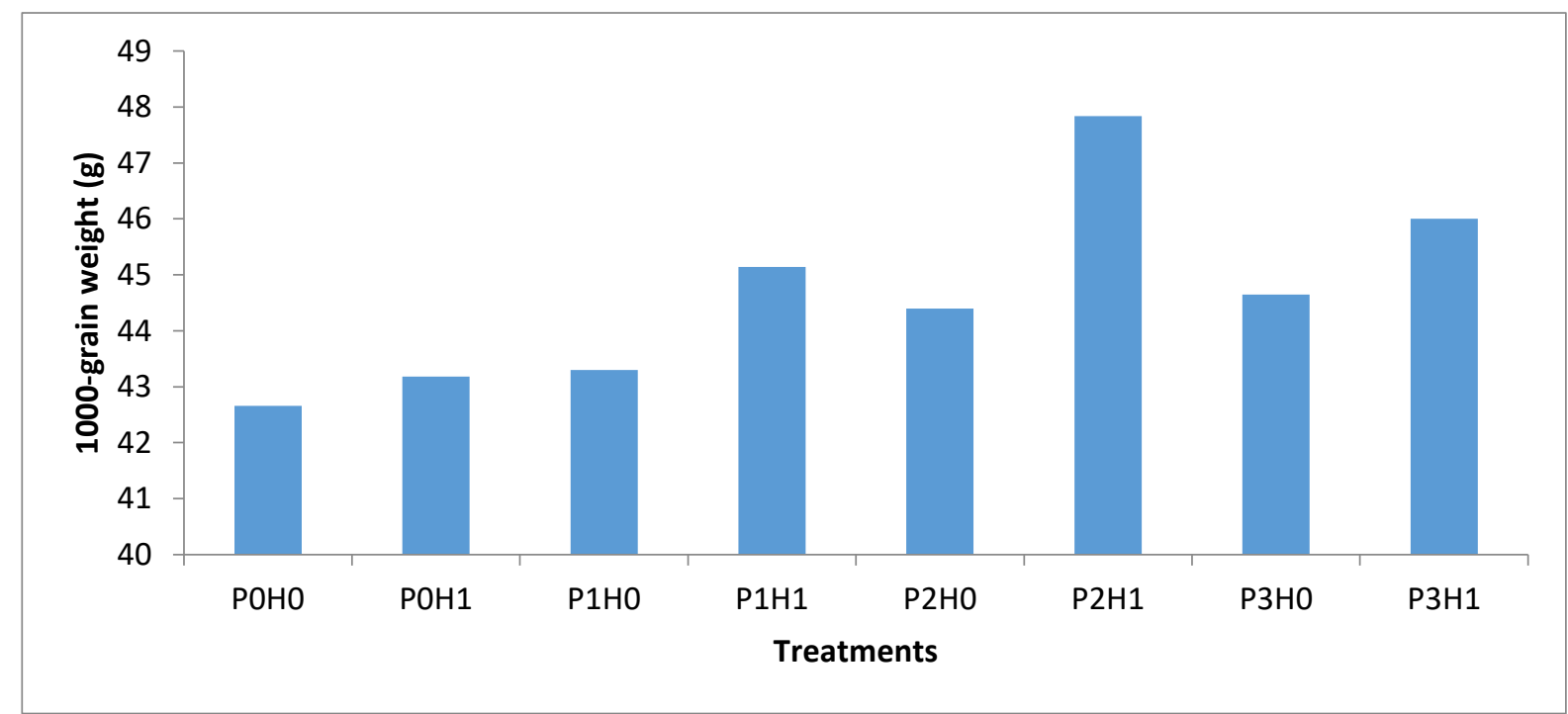

Figure 5. Effect of different treatments on 1000-grain weight (g) of wheat. 


\section{0 grain weight}

Data analysis regarding 1000- grain weight revealed that $\mathrm{HA}$ along with $90 \mathrm{~kg} \mathrm{ha}^{-1} \mathrm{P} 2 \mathrm{O} 5$ (P2H1) significantly increased 1000 - grain weight over control (Figure 5). The highest 1000- grain weight of $47.84 \mathrm{~g}$ was recorded in treatment $\mathrm{P} 2 \mathrm{H} 1$ (Table3). Furthermore all the levels of $\mathrm{P}$ either alone or in combination with HA increased 1000- grain weight but not significantly (Table 3 ). Published literature also confirmed increased in 1000- grain weight of wheat with HA application, Inamullah and Ali (2014) obtained maximum thousand grain weight (44.72 g) with $2 \mathrm{~kg} \mathrm{HA} \mathrm{ha}^{-1}$, while in another study Ulukan (2008) found maximum 1000- grain weight (38.08 g) of wheat $\begin{array}{lllll}\text { with } & 2 & \mathrm{~kg} & \mathrm{HA} & \mathrm{ha}^{-1} \text {. }\end{array}$

Table 3. Effect of different levels of phosphorous alone as well as in combination with humic acid on grain yield, total dry matter, Straw yield and 1000- grain weight of wheat.

\begin{tabular}{|c|c|c|c|c|}
\hline Treatments & Grain yield (kg ha-1) & TDM (kg ha $\left.{ }^{-1}\right)$ & Straw yield (kg ha-1) & 1000-grain weight (g) \\
\hline $\mathrm{PoH}_{\mathrm{O}}$ & $2936 c^{*}$ & $11683 d^{*}$ & $8748 d^{*}$ & $42.66 b^{*}$ \\
\hline $\mathrm{PoH}_{1}$ & $3732 b$ & $16534 \mathrm{c}$ & $12802 \mathrm{c}$ & $43.18 b$ \\
\hline $\mathrm{P}_{1} \mathrm{H}_{0}$ & $3839 \mathrm{~b}$ & $16969 \mathrm{bc}$ & $13130 \mathrm{bc}$ & $43.30 \mathrm{~b}$ \\
\hline $\mathrm{P}_{1} \mathrm{H}_{1}$ & 4697 a & $18556 \mathrm{abc}$ & $13859 \mathrm{abc}$ & $45.14 \mathrm{ab}$ \\
\hline $\mathrm{P}_{2} \mathrm{H}_{0}$ & $4800 \mathrm{a}$ & 20449 a & $15336 a b$ & $44.40 \mathrm{ab}$ \\
\hline $\mathrm{P}_{2} \mathrm{H}_{1}$ & $5112 a$ & $20877 a$ & 15906 a & $47.84 \mathrm{a}$ \\
\hline $\mathrm{P}_{3} \mathrm{H}_{0}$ & 4857 a & $19427 \mathrm{abc}$ & $14570 \mathrm{abc}$ & $44.65 \mathrm{ab}$ \\
\hline $\mathrm{P}_{3} \mathrm{H}_{1}$ & 4915 a & $19659 a b$ & $14749 a b c$ & $46.00 \mathrm{ab}$ \\
\hline
\end{tabular}

*Means with different letter (s) in columns are significantly different at $p<0.05$.

\section{Post harvest soil phosphorous concentrations and plant accumulation}

Application of different levels of P and HA either applied alone or in combination significantly $(P<0.05)$ increased soil $P$ concentration over control (Table 6).However non significant difference was found between $\mathrm{P}$ applied alone or reinforced with HA. Maximum post harvest soil $P$ concentration of $9.00 \mathrm{mg} \mathrm{kg}^{-1}$ was found in the treatment P3HO (Table 6, Fig.6). Both HA (POH1) and $P$ fertilizer $(\mathrm{P} 1 \mathrm{HO})$ applied alone showed non significant difference from each other. Similarly the treatments $\mathrm{P} 1 \mathrm{H} 1, \mathrm{P} 2 \mathrm{HO}, \mathrm{P} 3 \mathrm{HO}, \mathrm{P} 2 \mathrm{H} 1$, and $\mathrm{P} 3 \mathrm{HI}$ were significantly $(\mathrm{P}<0.05)$ different from control but showed non significant difference from each other. HA addition to the soil generally reduce $P$ fixation and increase the recovery of $\mathrm{P}$ ( Delgado et al., 2002;Satisha and Deverajan, 2005; Sharif et al., 2002).

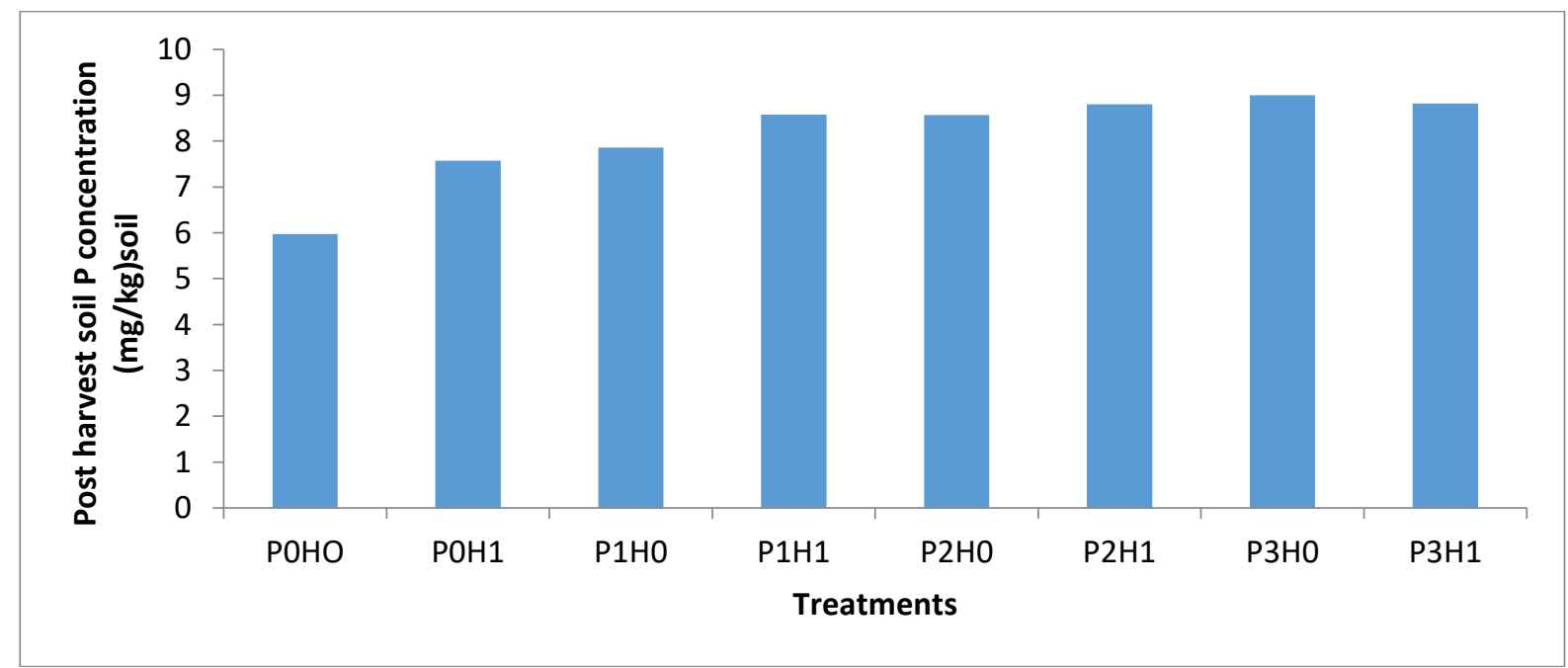

Figure 6. Effect of different treatments on post-harvest soil P concentration.

On the other hand $\mathrm{P}$ accumulation by wheat plants significantly $(P<0.05)$ increased over control by application of both $\mathrm{P}$ and $\mathrm{HA}$ either applied alone or in combination (Table 6 and Fig.7). Maximum $P$ accumulation of $18.53 \mathrm{~kg} \mathrm{ha}^{-1}$ was recorded in the treatment $\mathrm{P} 3 \mathrm{HO}$; however the treatment $\mathrm{P} 3 \mathrm{HI}$ showed a decline in $\mathrm{P}$ accumulation as compared to P3HO. HA had a significant effect on $\mathrm{P}$ concentration as well as an important factor in nutrients uptake (Canellas et al., 2002; Mahmoud and Hafez, 2010). 


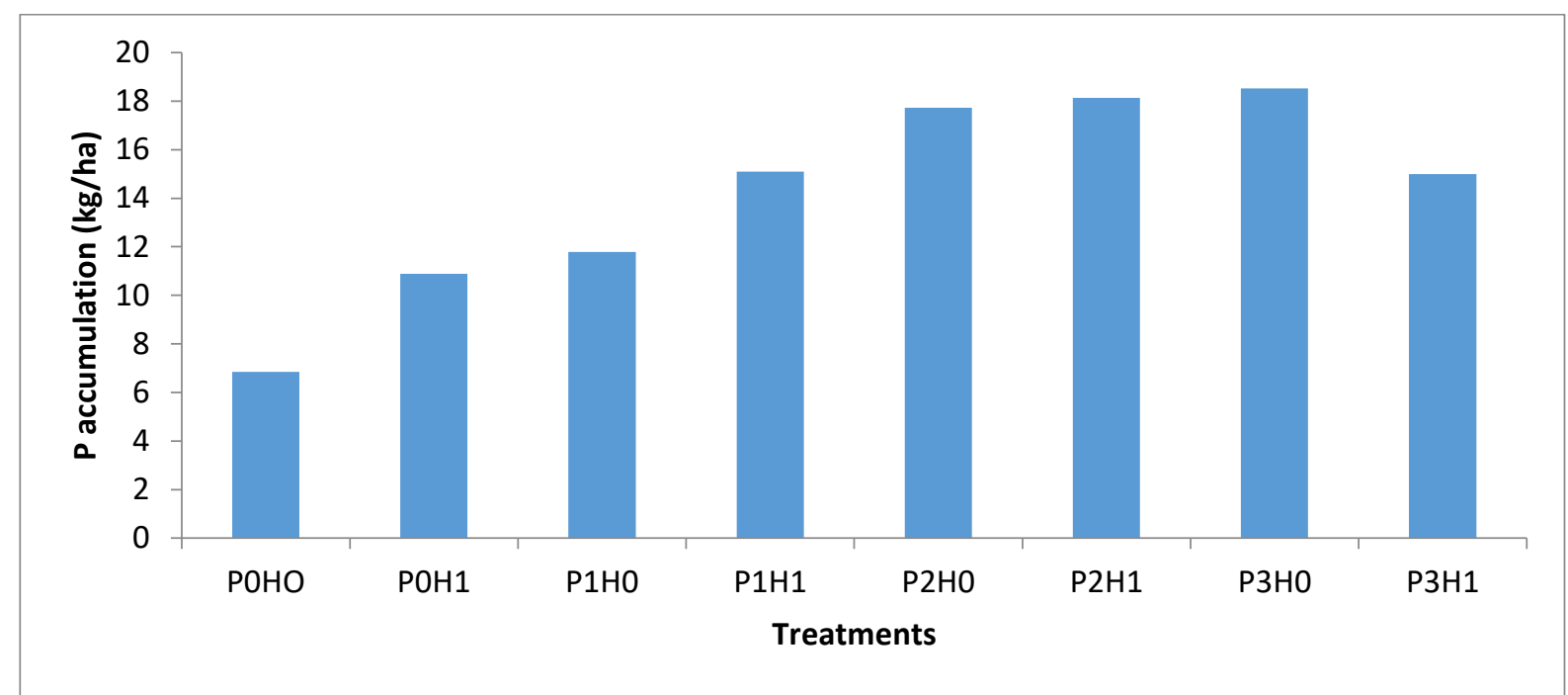

Figure 7. Effect of different treatments on $\mathrm{P}$ accumulation by wheat plants.

Table 6. Effect of different levels of $\mathrm{P}$ alone and in combination with HA on post harvest soil $\mathrm{P}$ concentration and its accumulation by wheat plants.

\begin{tabular}{ccc}
\hline Treatments & Available $\mathbf{P}$ concentration in soil $\left(\mathbf{m g ~ k g}^{-\mathbf{1}}\right)$ & Total $\mathbf{P}$ accumulated by wheat plants $\left(\mathbf{k g ~ h a}^{-\mathbf{1}}\right)$ \\
\hline $\mathrm{P}_{0} \mathrm{H}_{\mathrm{O}}$ & $5.97 \mathrm{c}^{*}$ & $6.85 \mathrm{e}^{*}$ \\
$\mathrm{P}_{0} \mathrm{H}_{1}$ & $7.57 \mathrm{~b}$ & $10.88 \mathrm{~d}$ \\
$\mathrm{P}_{1} \mathrm{H}_{0}$ & $7.86 \mathrm{~b}$ & $11.79 \mathrm{~d}$ \\
$\mathrm{P}_{1} \mathrm{H}_{1}$ & $8.58 \mathrm{a}$ & $15.09 \mathrm{c}$ \\
$\mathrm{P}_{2} \mathrm{H}_{0}$ & $8.57 \mathrm{a}$ & $17.72 \mathrm{ab}$ \\
$\mathrm{P}_{2} \mathrm{H}_{1}$ & $8.80 \mathrm{a}$ & $18.13 \mathrm{bc}$ \\
$\mathrm{P}_{3} \mathrm{H}_{0}$ & $9.00 \mathrm{a}$ & $18.53 \mathrm{a}$ \\
$\mathrm{P}_{3} \mathrm{H}_{1}$ & $8.82 \mathrm{a}$ & $15.00 \mathrm{c}$ \\
\hline
\end{tabular}

*Means with different letter(s) in columns are significantly different at $p<0.05$.

\section{Phosphorous use efficiency}

Phosphorous Use Efficiency (PUE) is the percent recovery of the applied nutrient in the harvested portion of crop. Maximum $P$ use efficiency was obtained with minimum fertilizer level reinforced with $\mathrm{HA}(\mathrm{P} 1 \mathrm{H} 1)$, while minimum
PUE was observed in the treatment $\mathrm{P} 3 \mathrm{H} 1$ supplied with highest fertilizer $P$ level of $150 \mathrm{~kg} \mathrm{ha}-1$ reinforced with HA (Table 7). Many investigators including (Sharif et al., 2002, Cimrinet al., 2010) concluded that crops utilize $5-35 \%$ of the applied $\mathrm{P}$ and the rest is retained in the soil.

Table 7. Effect of different levels of $\mathrm{P}$ alone and in combination with HA on $\mathrm{P}$ use effeciency.

\begin{tabular}{cccc}
\hline Treatments & P uptake $\left(\mathbf{k g ~ h a}^{-\mathbf{1}}\right)$ & P use efficiency (\%) & Yield increase (\%) \\
\hline $\mathrm{P}_{0} \mathrm{H}_{\circ}$ & $6.85 \mathrm{e}^{*}$ & & 27.1 \\
$\mathrm{PoH}_{1}$ & $10.88 \mathrm{~d}$ & & 30.7 \\
$\mathrm{P}_{1} \mathrm{H}_{0}$ & $11.79 \mathrm{~d}$ & 9.88 & 60.0 \\
$\mathrm{P}_{1} \mathrm{H}_{1}$ & $15.09 \mathrm{c}$ & 16.48 & 69.3 \\
$\mathrm{P}_{2} \mathrm{H}_{0}$ & $11.72 \mathrm{ab}$ & 10.87 & 74.1 \\
$\mathrm{P}_{2} \mathrm{H}_{1}$ & $18.13 \mathrm{bc}$ & 11.28 & 65.4 \\
$\mathrm{P}_{3} \mathrm{H}_{0}$ & $18.53 \mathrm{a}$ & 7.79 & 67.4 \\
$\mathrm{P}_{3} \mathrm{H}_{1}$ & $15.00 \mathrm{c}$ & 5.43 & \\
\hline
\end{tabular}

\section{Conclusions}

It was concluded from the results that the effect of HA on wheat yield is more pronounced at low level of SSP as compared to higher levels. Moreover $90 \mathrm{~kg} \mathrm{ha}^{-1} \mathrm{P}$ along with $500 \mathrm{~g} \mathrm{HA}$ was more effective in making the soil environment conducive for soil $P$ and for plant nutrients availibility. Organic matter status of soil could be built gradually by the use of small quantity of humic acid, combined application of chemical and organic fertilizers is inevitable and the use of humic acid alone can not substitute chemical fertilizers 
completely in case of wheat crop. Further investigations are strongly suggested to study the effect of different levels of $P$ alone as well as in combination with $\mathrm{HA}$ on various crops.

\section{References}

Aguirre, E., Leménager, D., Bacaicoa, E., Fuentes M., Baigorr, R.A., Zamarreño, A.M., GarcíaMina, J.M. 2009. The root application of a purified leonardite humic acid modifies the transcriptional regulation of the main physiological root responses to $\mathrm{Fe}$ deficiency in Fe sufficient cucumber plants. Plant Physiology \& Biochemisty, 47:215223.

Ahmad, M., Khan, M.J., Muhammad, D. 2013. Response of maize to different phosphorus levels under calcareous soil conditions. Sarhad J. Agric., 29(1): 43-48.

Inamullah, N., Ali. 2014. Assessment of various humic acid and sulfur levels for higher yields in wheat (Triticum aestivum L.). Sarhad Journal of Agriculture, 30(1): 47-52.

Ali M., Mindari W. 2016. Effect of humic acid on soil chemical and physical characteristics of embankment. In MATEC Web of Conferences (Vol. 58). EDP Sciences.

Anwar, A., Yousaf, M. 2000. effect of farm yard manure and chemical fertilizers on wheat under rainfed conditions. Soil Sci. Soc. of Pak.

Brunetti, G., Senesi, N., Plaza, C. 2007. Effects of amendment with treated and untreated olive oil mill wastewaters on soil properties, soil humic substances and wheat yield. Geoderma, 138(1-2): 144-152.

Canellas, L., Olivares, F., Olofrokovha-Facanha, A., Facanha, A. 2002. Humic acids isolated from earthworm compost enhance root elongation, lateral root emergence, and plasma membrane $\mathrm{H}+$ ATPase activity in maize roots. Plant Physiology 130: 19511957.

Chen, Y., Nobili, M.D.E., Aviad, T.2004. In stimulatory effects of humic substances on plant growth. soil organic matter in sustainable agriculture, CRC Press, Boca Raton, Florida p.103-129.

Cheryl, M., Grossl, P., Bugbee, B. 2001. Beneficial effects of humic acid on micronutrient availability to wheat. Soil Sci. Soc. Amer. J., 65: 1744-1750.

Çimrin, K.M., Türkmen, Ö., Turan, M., Tuncer, B. 2010. Phosphorus and humic acid application alleviate salinity stress of pepper seedling. African Journal of Biotechnology, 9(36).
Delgado, A., Madrid, A., Kassem, S., Andreu, L., Del Campillo, M.D.C. 2002. Phosphorus fertilizer recovery from calcareous soils amended with humic and fulvic acids. Plant and Soil, 245(2): 277-286.

Ezzat, A.S., Saif, U.M., Eldeen Abdul-Hameed, A.M. 2009. Effect of irrigation water quantity, anti-transparent and humic acid on growth, yield, nutrients content and water use efficiency of potato (Solanum tuberosumL.). J. Agric. Sci. Mansoura Univ., 34: 1158511603.

Julie, C., Bugbee, B. 2006. The use of humic acid to ameliorate iron deficiency stress. Biol. Biochem., 2: 67-71.

Karakurt Y., Unlu H., Padem H., 2009. The influence of foliar and soil fertilization of humic acid on yield and quality of pepper. Acta Agriculturae Scandinavica, Section B, Soil and Plant Science, 59: 233-237.

Khaled, H., Fawy, H.A., 2011. Effect of different levels of humic acids on the nutrient content, plant growth, and soil properties under conditions of salinity. Soil and Water Research, 6(1): 21-29.

Khattak, R.A., Muhammad, D. 2008. Increasing crop production through humic acid in salt affected soils in Kohat Division (NWFP). PakUs Collaborative Research Endeavor, ALP Project, PARC, Islamabad.

Khan, R.U., Rashid, A., Khan, M.S., Ozturk, E. 2010. Impact of humic acid and chemical fertilizer application on growth and grain yield of rainfed wheat (Triticum aestivum L.). Pakistan Journal of Agricultural Research, 23.

Latif, A., Iqbal, Z., Ali, S., Iqbal, M. 2003. Improvement in phosphorous fertilizer efficiency by fertilization in some winter vegetables. Pakistan J. Soil Sci., 22(3): 82-83.

Li. S., Li. J., Li. G., Li. Y., Yuan. J., Li. D. 2017. effect of different organic fertilizers application on soil organic matter properties. Compost Science \& Utilization, 25(1): 31-36.

Mahmoudi, A.R., Hafez, M.M. 2010. Increasing productivity of potato plants (Solanum tuberosum, L.) by using potassium fertilizer and humic acid application. Int. J. Acad. Res., 2: 83-88.

Manzoor A., Khattak RA., Dost M., 2014. Humic acid and micronutrient effects on wheat yield and nutrients uptake in salt affected soils. Int. J. Agric. Biol., 16(5): 991-995.

MINFA, 2011. Govt. of Pakistan, Ministry of Food and Agric., Econ. Wing, Islamabad.

Naseer, M., Muhammad, D., 2014. Direct and residual effect of hazara rock phosphate 
(HRP) on wheat and succeeding maize in alkaline calcareous soils. Pak. J. Bot., 46(5): 1755-1761.

Nelson DW, Sommers LE. 1982. Total carbon, organic carbon and organic matter. In: Methods of Soil Analysis. (Eds.): A.L. Page. Part 2 .2nd edt. AM. Soc. Agron. Inc. Madison WI. USA.

Quan-Xian, H.U.A., Jian-Yun, L.I., Jian-Min, Z.H.O.U., Huo-Yan, W., Chang-Wen, D.U., Xiao-Qin, C. 2008. Enhancement of phosphorus solubility by humic substances in Ferrosols1. Pedosphere, 18(4): 533-538.

Richards LA., 1954. Diagnosis and improvement of saline and alkali soils. USDA Handbook 60. Washington DC.

Satisha, G., Devarajan, L., 2005. Humic substances and their complexation with phosphorus and calcium during composting of pressmud and other biodegradables. Communications in Soil Science and Plant Analysis, 36: 805818.

Selim, E.M., El-Neklawy, A.S., El-Ashry, S.M., 2009. Beneficial effects of humic substances fertigation on soil fertility to potato grown on sandy soil. Aust. J. Basic Appl. Sci., 3:4351-4358.

Sharif, M., Khattak, R.A., Sarir, M.S., 2002. Wheat yield and nutrients accumulation as affected by humic acid and chemical Fertilizers. Sarhad Journal of Agriculture, 18: 323-329.

Soltanpour, P.N. 1985. Use of AB-DTPA soil test to evaluate elemental variability and toxicity. Commun. Soil Sci. Plant Anal., 16: 323-338.

Steel, R.G., Torrie, J.H. 1980. Principles and procedures of statistics. A biometrical approach. McGraw-Hill, New York.

Stott, D.E., Martin, J.P. 1990. Synthesis and degradation of natural and synthetic humic materials in soils. Humic Substances in Soil and Crop Sciences: Selected Readings. ASA and SSSA, Madison, WI., 37-63.

Sutton, R., Sposito, G. 2005. Molecular structure in soil humic substances: The New View, Environ. Sci. Technol., 39: 9009-9015.

Ulukan H. 2008. Effect of soil applied humic acid at different sowing times on some yield components in wheat (Triticum spp.) hybrids. Int. J. Bot., 4(2): 164-175.

Walsh, L.M., Beaton, J.D. 1973. Soil Testing and Plant Analysis.

Wang, Z.H., Miao, Y.F., Li, S.X. 2015. Effect of ammonium and nitrate nitrogen fertilizers on wheat yield in relation to accumulated nitrate at different depths of soil in drylands of China. Field Crops Research, 183: 211224. 